\title{
Rekonsepsi Model Pencegahan dan Pemberantasan Illegal Fishing di Indonesia
}

\author{
Muh. Risnain* \\ DOI: https://doi.org/10.22304/pjih.v4n2.a9
}

\begin{abstract}
Abstrak
Pencegahan dan pemberantasan illegal fishing di Indonesia adalah isu hukum yang masih dapat diperdebatkan hingga kini. Dibalik popularitas kebijakan pencegahan dan pemberantasan illegal fishing ternyata masih menimbulkan masalah yang masih diperdebatkan baik secara teoritis maupun praktikal. Model kebijakan pencegahan dan pemberantasan illegal fishing yang dilakukan dengan penenggelaman kapal dan penangkapan kapal asing masih menghadapi persoalan yang harus diselesaikan dengan sebuah model pencegahan dan pemberantasan illegal fishing secara komprehensif dan terkoordinasi. Model baru tersebut untuk menyempurnakan model yang ada sekarang dengan dukungan pada pemodelan kelembaagaan, pengayaan rezim hukum, kerjasama internasional, dan koordinasi dengan lembaga penegakan hukum perikanan di daerah.
\end{abstract}

Kata kunci: komprehensif, koordinasi, model, pemberantasan, pencegahan.

\section{The Re-Conception of Illegal Fishing Prevention and Eradication Model in Indonesia}

\begin{abstract}
The prevention and eradication of illegal fishing in Indonesia is a legal issue that still being an on going debate. Beyond the popularity of policy in order to prevent and eradicate illegal fishing, there remains a theoritically and practically issues.. The policy model in preventing and eradicating illegal fishing through shinking the vessel and catching foreign vessel are also in need of a comprehensive and coordinated prevention and eradication of illegal fishing. The purpose of the new model is to enhance the old model with the support of institutional modeling, multi-legal regime, international cooperation, and coordination with legal officer in regional area.
\end{abstract}

Keywords: comprehensive, coordination, model, eradication, prevention.

\section{A. Pendahuluan}

Sejak dilantik menjadi Presiden Indonesia pada tahun 2014, Presiden Joko Widodo memperkenalkan visi Indonesia sebagai negara maritim. Program itu dituangkan dalam berbagai program di bidang kelautan yang juga merupakan program nawa cita. Visi presiden itu kemudian dilaksanakan oleh Menteri Susi Pudjiastuti melalui pemberantasan illegal fishing di wilayah perairan Indonesia. Kebijakan peneng-

PADJADJARAN Jurnal IImu Hukum Volume 4 Nomor 2 Tahun 2017 [ISSN 2460-1543][e-ISSN 2442-9325]

* Dosen Fakultas Hukum Universitas Mataram, Jl. Majapahit No. 62, Mataram, NTB, risnain82@gmail.com, S.H. (Universitas Mataram), M.H., Dr. (Universitas Padjadjaran). 
gelaman kapal asing menjadi program primadona di bidang maritim yang mendapat apresiasi publik.

Kebijakan pencegahan dan pemberantasan illegal fishing melalui penenggelaman kapal asing yang mulai gencar dilakukan sejak tahun 2015 memberikan dampak yang luar biasa bagi kedaulatan, ekonomi dan lingkungan laut. Melalui penegakan hukum di laut terhadap kapal asing maupun kapal pelaku illegal fishing telah menghadirkan negara sebagai pemilik kedaulatan di laut. Kehadiran negara di laut telah mampu menyelamatkan potensi pendapatan negara yang selama ini dinikmati nelayan asing. Pemberantasan illegal fishing menaruh harapan untuk menyelamatkan sumber daya perikanan dan menjamin perikanan berkelanjutan. ${ }^{1}$

Walaupun menjadi program kebanggaan Presiden Joko Widodo, namun pada tataran konsep dan praktik pencegahan dan pemberantasan illegal fishing di perairan Indonesia. Pencegahan dan pemberantasan illegal fishing yang hanya mengedepankan penegakan hukum dengan pendekatan tindak pidana perikanan ternyata belum mampu menyelesaikan masalah kompleks di bidang illegal fishing. Kejahatan illegal fishing bukanlah kejahatan yang bersifat tunggal tetapi berkaitan dengan tindak pidana yang lain yang berhubungan dengan tindak pidana perikanan (fishing crime) seperti perdagangan manusia, pencucian uang, kerja paksa, kejahatan di bidang minyak dan gas bumi yang tentu memerlukan pendekatan konsep yang lain dari konsep saat ini. Begitu juga pada persoalan penegak hukum, model pembentukan satuan tugas (satgas) 115 seperti yang ada saat ini ternyata belum maksimal menghadirkan hasil maksimal bagi pencegahan dan pemberantasan illegal fishing di perairan Indonesia. ${ }^{2}$

Terdapatnya unsur kejahatan transnasional dalam elemen kejahatan illegal fishing dan fishing crime ini menyebabkan dibutuhkan kerja sama internasional untuk mengatasinya. Hingga kini belum ada kerja sama internasional yang dapat dimanfaatkan Indonesia untuk memberantas illegal fishing dan fishing crime sebagai sebuah kejahatan yang memerlukan kerjasama internasional. Hukum internasional belum menjadikan illegal fishing sebagai kejahatan yang memiliki karakteristik lintar batas negara (transnasional organized crime). Begitu juga dengan koordinasi pencegahan dan pemberantasan illegal fishing dengan pemerintah daerah. Hingga kini belum ada mekanisme koordinasi antara pemerintah daerah dengan pemerintah pusat dalam upaya pencegahan dan pemberantasan illegal fishing. ${ }^{3}$

1 Diding Sutardi, “Tak Ada Tempat Bagi Perampok Ikan”, Majalah Mina Bahari, Edisi 01, Apr - Jun 2015, hlm. 12.

2 Pocut Eliza, Laporan Akhir Analisis Dan Evaluasi Hukum Dalam Rangka Pemberantasan Kegiatan Perikanan Liar (IUU fishing), Jakarta: Pusat Analisis dan Evaluasi Hukum Nasional, Badan Pembinaan Hukum Nasional Kementerian Hukum dan HAM RI Tahun 2016, hlm. 107.

3 Susi Pudjiastuti, "Fisheries Crime As Transnational Organized Crime”, Makalah disampaikan pada Pertemuan di Singapura, 17 November 2015, hlm. 14. 
Tulisan ini bermaksud menawarkan sebuah konsep baru model pencegahan dan pemberantasan illegal fishing sebagai tawaran konsep yang dapat digunakan pemerintah dalam mendesain dan melaksanakan kebijakan pencegahan dan pemberantasan illegal fishing di Indonesia pada masa yang akan datang.

\section{B. Pencegahan dan Pemberantasan Illegal Fishing dalam Perspektif Pembangunan Perikanan Berkelanjutan}

Konsep pembangunan berkelanjutan menurut Daud M Silalahi ${ }^{4}$ merupakan konsep yang genuine-nya berasal dari konsep ilmu ekonomi terkait persoalan efisiensi dan keadilan untuk menjamin keberlanjutan pembangunan ekonomi bagi kesejahteraan masyarakat. Pengertian dari segi ekonomi ini juga dilatarbelakangi oleh ilmu biologi yang membahas keberlanjutan dari segi kemampuan dan kesesuaian (capability and surtability) suatu relasi dengan potensi regenerasi/produktivitas lingkungan hidupnya.

Dalam kajian ilmu biologi, konsep berkelanjutan (sustainability) telah lama dikenal. Pada konferensi "Analisa dan Manajemen Penggunaan Berkelanjutan Tanah Hutan Tropis" (Forests Land Assessment and Management for Sustainable Uses) perkataan 'sustainable use' diartikan sebagai: "continuing national use of land without severe or permanent deterioration in the quality and quantity of one or more component of the integrated ecosystem or landscape unit". Dalam pada itu, istilah 'pembangunan berkelanjutan' atau sustainable development merupakan konsep baru yang terkait dengan konsep pembangunan. Arti keterkaitan ini dapat dihubungkan dengan masalah efisien dan keadilan. Melakukan efisien untuk memperbesar hasil pembangunan, dan keadilan (equity) untuk pembagian yang layak dan menjaga keberlanjutan pemanfaatannya.

Pengertian pembangunan berkelanjutan dapat ditemukan baik secara eksplisit maupun implisit dalam berbagai perjanjian internasional dan berbagai instrumen lainnya. Laporan Komisi Brundtland pada tahun 1987 merupakan pengertian hukum yang luas dan dianut secara luas yang memberikan pengertian 'sustainable development' sebagai "development that meets the needs off the present without compromising the ability of future generation to meet their own needs". 5 Terdapat 2 (dua) konsep penting dalam rumusan di atas. Pertama, konsep kebutuhan (needs) terutama kebutuhan dasar generasi saat ini, dan kedua, ide keterbatasan yang didasarkan pada pertimbangan kemajuan teknologi dan organisasi sosial untuk

4 Daud Silalahi, “Pembangunan Berkelanjutan Dalam Rangka Pengelolaan (Termasuk Perlindungan) Sumber Daya Alam Yang Berbasis Pembangunan Sosial Dan Ekonomi”, Makalah Disampaikan Pada Seminar Pembangunan Hukum Nasional VIII Tema Penegakan Hukum Dalam Era Pembangunan Berkelanjutan, diselenggarakan oleh Badan Pembinaan Hukum Nasional Departemen Kehakiman Dan Hak Asasi Manusia RI Denpasar, 14-18 Juli 2003, hlm. 20.

$5 \quad$ Philipe Sands, Principles of International Environmental Law, 1995, hlm. 11. 
menetapkan daya dukung lingkungan yang mampu menopang kehidupan generasi sekarang dan generasi masa depan.

Laporan Brundtland mengidentifikasikan beberapa masalah kritis yang perlu dijadikan dasar kebijakan lingkungan bagi konsep pembangunan berkelanjutan, yakni:

a) Mendorong pertumbuhan dan meningkatkan kualitas (reviving growth and changing its quality);

b) Mendapat kebutuhan pokok mengenai pekerjaan, makanan energi, air, dan sanitasi (meeting essential needs for jobs, food, energy, water, and sanitation);

c) Menjamin tingkat pertumbuhan penduduk yang mendukung keberlanjutan (ensuring a sustainable level of population).

d) Melakukan konservasi dan kemampuan sumber daya (conserving and enhancing the resource base);

e) Orientasi teknologi dan mengelola risiko (reorienting technology and managing risks); dan

f) Memadukan pertimbangan lingkungan ekonomi dalam proses pengambilan keputusan (merging environment and economics in decision-making) ${ }^{6}$

Restrukturisasi ekonomi internasional dan lahirnya hukum pembangunan internasional telah menampilkan satu dimensi baru konsep pembangunan dunia saat ini. Dimensi lingkungan dalam konsep pembangunan Perserikatan BangsaBangsa (PBB) muncul ketika evaluasi konsep pembangunan dunia tahap pertama (1960-70) dikaji ulang bagi penyusunan pembangunan PBB tahap II. Pada konferensi PBB tahun 1972, untuk pertama kalinya ditetapkan pertimbangan lingkungan sebagai bagian dari konsep pembangunan.

Konferensi PBB tentang Pembangunan dan Lingkungan (United Nations Conference on Environment and Development) yang diadakan di Rio de Janeiro pada tahun 1992 merupakan kritik terhadap konsep pembangunan yang berwawasan lingkungan (eco-development) yang dianggap gagal karena tidak membawa perubahan signifikan. Perkembangan ilmu dan teknologi baru, misalnya, dianggap tidak membawa keadilan bagi negara berkembang, sebab sekitar $70 \%$ penduduk dunia yang berada di negara berkembang hanya memperoleh $30 \%$ dari pendapat dunia yang akan menimbulkan ketidakadilan yang berkelanjutan. Berkat dari pekerjaan yang serius dari Komisi Dunia Pembangunan dan Lingkungan atau dikenal sebagai The World Commission on Environment and Development, dikenal pula sebagai The Brundtland Commission, dalam laporannya yang berjudul Our Common Future mengembangkan konsep pembangunan berkelanjutan (sustainable development). Produk dari era konferensi Rio di atas

6 Daud Silalahi, Peranan Hukum dalam Mengaktualisasikan Prinsip-Prinsip Pembangunan Berkelanjutan, Bandung: Alumni, 1997, hlm. 23. 
tercermin antara lain dalam konvensi keanekaragaman hayati (biodiversity convention), Konvensi Perubahan Iklim (Climate Change Convention), dan suatu Deklarasi Pembangunan berkelanjutan Pengelolaan Hutan, serta Agenda 21. Pengaruh dari perkembangan baru ini dengan segera pula mempengaruhi kebijakan dan hukum lingkungan di berbagai negara, termasuk Indonesia.

Menurut Gatot Dwi Hendro Wibowo, ${ }^{7}$ konsep pembangunan berkelanjutan (sustainable development) merupakan etika politik pembangunan yaitu komitmen moral tentang cara dan metode pembangunan dilaksanakan untuk mencapai tujuan. Makna etika politik dalam pembangunan menurut beliau harus dimaknai secara komprehensif sebagai yang bukan saja hanya konsep yang bisa dikaitkan dengan kepentingan perlindungan lingkungan semata, bukan juga kepentingan pembangunan ekonomi. ${ }^{8}$

Pembangunan berkelanjutan menghendaki adanya sinkronisasi, integrasi dengan porsi sama antara kepentingan ekonomi, sosial budaya dan lingkungan dalam proses pembangunan. Ketiga aspek tersebut merupakan satu kesatuan yang tidak dapat dipisahkan. Pencapaian ekonomi tetap dibiarkan menuju pertumbuhan perekonomian tetapi di pihak yang lain lingkungan tetap dipelihara begitu juga sosial budaya juga tetap diperhatikan. ${ }^{9}$

Lebih lanjut Gatot Dwi Hendro Wibowo menyatakan makna pembangunan berkelanjutan mengandung 2 (dua) wajah, yaitu kritik pada paradigma 'developmentalisme' sekaligus menyodorkan paradigma baru pembangunan. Konsep baru ini menghendaki agar pembangunan tidak saja pada pendekatan 'developmentali's semata tetapi pembangunan juga memperhatikan kepentingan pelestarian fungsi lingkungan hidup dan sosial budaya manusia..$^{10}$ Menurut Turner, AK pembangunan berkelanjutan "in principle, such an optimal (sustainable growth) policy would seek to maintain an "acceptable" rate of in-percapita real incomes without depleting the national capital asset stock or the natural environmental asset stock".

Menurut M.C.W. Pinto terkait pembangunan berkelanjutan:

"The word development appearing was used to convoy a meaning quite distinct from "economic development". The term "sustainable development" ... used there to describe the concept of managing a given resources with a view to its conversations, implying regulation of the use and exploitation of the resource in such a manner that its

7 Gatot Dwi Hendro Wibowo, Hukum Konservasi Lautan: Kerangka Hukum Pengelolalaan Ekosistem Terumbu Karang untuk Keanekaragaman Hayati Lautan, 2010, hlm. 52.

$8 \quad$ Ibid.

9 Siti Sundari Rangkuti, Hukum Lingkungan dan Kebijaksanaan Lingkungan Nasional, Edisi Kedua, Air Langga University Press, 2000, hlm. 90.

10 Koesnadi Hardjasoemantri, Hukum Tata Lingkungan, Edisi Ke-7, Cetakan ke-17, Yogyakarta: Gadjah Mada University Press, 1999, hlm. 50. 
benefits are optimized, or made available on an equitable basis for the largest number over long term."

Berdasarkan pendapat Roberto Ropetto:

"Sustainable development is a developmental strategy that manages all assets, natural resources as well as financial and physical assets for increasing long-term wealth and well-being. Sustainable development as goal rejects policies and practices that support current living standards by depleting the productive base, including natural resources and that leaves future generation with poorer prospects and great risks than our own."

Menurut Dietrecht G Bangen, pembangunan berkelanjutan adalah suatu strategi pemanfaatan ekosistem alamiah sedemikian rupa sehingga kapasitas fungsionalnya untuk memberikan manfaat kehidupan manusia tidak rusak. Lebih lanjut beliau mengatakan pembangunan berkelanjutan memiliki 4 (empat) dimensi, yakni: (1) ekologis; (2) sosial-ekonomi budaya; (3) sosial politik; dan (4) hukum dan kelembagaan. Pendapat Biliana Cicin-Sain dan Robert W Knecht mengatakan pembangunan berkelanjutan sebagai berikut:

"A continues process of decision making guided by a basic philosophy emphasizing development that improves are quality of human life (ensuring equity in the distribution of benefits flowing from development) and development that is appropriate, making proper use (and sometime non use) of natural resources and protecting essential ecological processes, life support system and biological diversity."

\section{Rekonsepsi Model Pencegahan dan Pemberantasan Illegal Fishing di Indonesia}

Pada penelitian terdahulu telah disimpulkan 2 (dua) simpulan penting: pertama, penyebab terjadinya illegal fishing disebabkan oleh beberapa hal, yakni; peningkatan permintaan produk perikanan di pasar lokal maupun global, subsidi sektor perikanan yang over kapasitas, berkurangnya kemampuan negara untuk mengkontrol kapal perikanan, dan tidak efektifinya kontrol, pemantauan terhadap kegiatan perikanan. ${ }^{11}$ Dampak illegal fishing berdampak pada kerusakan ekosistem perikanan yang membahayakan perikanan berkelanjutan, kerugian ekonomi negara dan mengancam kedaulatan negara. Kedua, beberapa kebijakan pencegahan dan pemberantasan illegal, unreported, and unregulated fishing (IUU fishing) yang telah diambil pemerintah Indonesia. Kebijakan pencegahan dilakukan dengan cara: moratorium perizinan penangkapan ikan dan eks kapal asing di Indonesia, larangan

11 Dikdik Mohamad Sodik, “Combating Illegal, Unreported, and Unregulated Fishing in Indonesian Waters: Need for Fisheries Legislative Reform”, Disertasi, Wolonglong University, 2007, hlm. 125. 
penggunaan pukat hela dan pukat tarik, serta larangan penangkapan ikan di Laut Banda. Kebijakan pemberantasan illegal fishing di Indonesia dilakukan dengan pembentukan pengadilan perikanan, penenggelaman kapal asing yang melakukan illegal fishing, dan pembentukan satgas Illegal Fishing.

Lalu ketiga, model pencegahan dan pemberantasan illegal fishing di Indonesia dilakukan dengan cara, pertama, mengetahui sebab terjadinya illegal fishing, dampak illegal fishing, modus illegal fishing, dan persoalan-persoalan yang dihadapi dalam penegakkan hukum illegal fishing di Indonesia. Kedua, untuk mewujudkan pencegahan dan pemberantasan illegal fishing di Indonesia yang efektif maka dilakukan dengan mengambil kebijakan legislasi dengan merancang undang-undang pemberantasan illegal fishing yang akan mengatur sistem pencegahan dan pemberantasan illegal fishing di Indonesia.

Berbagai kebijakan pencegahan dan pemberantasan yang telah dilakukan Pemerintah Indonesia ternyata belum mampu secara komprehensif menyelesaikan masalah illegal fishing di Indonesia. Untuk menyelesaikan masalah-masalah pencegahan dan pemberantasan illegal fishing di atas maka Penulis menemukan dan menawarkan sebuah model pencegahan dan pemberantasan illegal fishing di Indonesia. Model pencegahan dan pemberantasan illegal fishing yaitu model pencegahan dan pemberantasan illegal fishing yang komprehensif dan terkoordinasi (comprehensive and coordinated in preventing and combating illegal fishing).

Pembentukan model pencegahan dan pemberantasan illegal fishing yang komprehensif dan terkoordinasi didasarkan pada pemikiran yang sesuai dengan visi Indonesia sebagai negara maritim yang memandang laut sebagai masa depan bangsa. Untuk membangun negara maritim maka dibangun dengan lima pilar, yaitu: 1) pembangunan budaya maritim; 2) penjagaan dan pengelolaan sumber daya laut; 3) pembangunan infrastruktur dan konektifitas; 4) melakukan diplomasi maritim untuk menghilangkan konflik di laut dengan negara lain; dan 5) pembangunan dan keselamatan di laut.

Di samping visi dan pilar negara maritim di atas, hal yang menjadi dasar pijakan berpikir pembentukan konsep visi pembangunan di bidang kelautan dan perikanan yakni “Mewujudkan Sektor Kelautan dan Perikanan Indonesia Yang Mandiri, Maju, Kuat dan Berbasis Kepentingan Nasional" yang ditetapkan oleh Kementerian Kelautan dan Perikanan Indonesia. Untuk mewujudkan visi tersebut maka ditetapkanlah visi dan pilar pembangunan kelautan dan perikanan yaitu kedaulatan (sovereignty), keberlanjutan (sustainability), dan kesejahteraan (prosperity). ${ }^{12}$

Kedaulatan negara di wilayah laut adalah kekuasaan negara menurut hukum internasional untuk mengatur, melaksanakan, dan menegakan hukum di wilayah

12 Kementerian Kelautan dan Perikanan, Laporan Satu Tahun Kinerja KKP, Jakarta: KKP RI, 2015, hlm. 8. 
berdaulat negara dan wilayah hak berdaulat..$^{13}$ Kedaulatan negara secara eksplisit telah diakui dalam Pasal 2 Konvensi Hukum Laut 1982. ${ }^{14}$ Dengan demikian, kedaulatan negara atas wilayah laut merupakan hak dan kewenangan negara yang legitimate dan diotorisasi oleh hukum internasional. Berdasarkan hasil penelitian pada kementerian kelautan dan perikanan RI, kedaulatan negara di laut menurut Kementerian Kelautan dan Perikanan dimaknai sebagai kemandirian dalam mengelola dan memanfaatkan sumber daya kelautan dan perikanan dengan memperkuat kemampuan nasional untuk melakukan penegakan hukum di laut demi mewujudkan kedaulatan secara ekonomi, yang dilakukan melalui pengawasan pengelolaan Sumber Daya Kelautan dan Perikanan (SDKP) dan sistem perkarantinaan ikan, pengendalian mutu, keamanan hasil perikanan, dan keamanan hayati ikan.

Untuk mendesain model pencegahan dan pemberantasan illegal fishing yang komprehensif dan terkoordinasi (compressive and coordinated in preventing and combating illegal fishing) maka peneliti mengajukan beberapa elemen pembentuk konsep sebagaimana dipaparkan di bawah ini.

\section{Model Kelembagaan Pencegahan dan Pemberantasan Illegal Fishing}

Desain kelembagaan pencegahan dan pemberantasan Illegal fishing di Indonesia dilakukan melalui sistem peradilan pidana perikanan dan pembentukan satgas illegal fishing yang berada di bawah komando presiden. Sistem peradilan pidana perikanan tersebut melibatkan penyidik, penuntut umum, dan pengadilan perikanan, sedangkan satgas melibatkan lembaga-lembaga eksekutif yang berada di bawah presiden.

Di bidang penyidikan tindak pidana perikanan, Undang-Undang Nomor 45 Tahun 2009 tentang Perubahan terhadap Undang-Undang Nomor 31 Tahun 2004 tentang Perikanan (UU Perikanan) mendesain kewenangan kelembagaan berdasarkan pada konsep multi-institusi. Penyidikan tindak pidana perikanan di wilayah pengelolaan perikanan Negara Republik Indonesia dilakukan oleh Penyidik Pegawai Negeri Sipil Perikanan, Penyidik Perwira Tentara Nasional Indonesia Angkatan Laut (TNI-AL), dan/atau Penyidik Kepolisian Negara Republik Indonesia (Polri). Tindak pidana perikanan yang locus delicti-nya terjadi di Zona Ekonomi Eksklusif (ZEE) Indonesia maka kewenangan penyidikan dimiliki penyidik TNI AL dan Penyidik Pegawai Negeri Sipil Perikanan Tindak Pidana Perikanan, sedangkan apabila locus delicti-nya di pelabuhan perikanan maka diutamakan dilakukan oleh Penyidik Pegawai Negeri Sipil Perikanan. Masing-masing penyidik di atas memiliki

13 Dikdik Mohamad Sodik, Hukum Laut Internasional dan Pengaturannya di Indonesia, Bandung: Refika Aditama, 2014, hlm. 75.

14 Etty R Agoes, Konvensi Hukum Laut 1982: Masalah Pengaturan Hak Lintas Kapal Asing, CV. Abardin, 1991. 
independensi, namun dalam hubungan kerja dalam penanganan perkara tindak pidana perikanan antara penyidik melakukan hubungan koordinasi. Kelembagaan hubungan koordinasi di antara para penyidik tersebut dilakukan dengan membentuk forum koordinasi yang dibentuk oleh menteri perikanan dan kelautan. ${ }^{15}$

Di bidang penuntut umum, desain kelembagaan dilakukan oleh penuntut umum yang ditetapkan oleh Jaksa Agung. Penuntut umum tindak pidana perikanan didesain untuk dilakukan oleh penuntut umum yang memenuhi persyaratan khusus, yaitu: a. berpengalaman menjadi penuntut umum sekurang-kurangnya 2 (dua) tahun; b. telah mengikuti pendidikan dan pelatihan teknis di bidang perikanan; dan c. cakap dan memiliki integritas moral yang tinggi selama menjalankan tugasnya.

Di bidang kekuasaan kehakiman UU Perikanan, guna mendesain tindak pidana perikanan sebagai tindak pidana khusus maka dibentuklah pengadilan perikanan. Pengadilan perikanan yang berwenang memeriksa, mengadili, dan memutus tindak pidana di bidang perikanan. Pengadilan perikanan merupakan pengadilan khusus yang berada dalam lingkungan peradilan umum. Pada awal pendirian pengadilan perikanan dibentuk di Pengadilan Negeri Jakarta Utara, Medan, Pontianak, Bitung, dan Tual. Pengadilan perikanan berkedudukan di pengadilan negeri. UU Perikanan ini mengambil kebijakan pembentukan pengadilan perikanan yang dilakukan secara bertahap sesuai dengan kebutuhan yang ditetapkan dengan keputusan presiden.

Selain kelembagaan sistem peradilan pidana di bidang perikanan di atas, Presiden Joko Widodo melalui Peraturan Presiden Republik Indonesia Nomor 115 Tahun 2015 Tentang Satuan Tugas Pemberantasan Penangkapan Ikan Secara llegal (IIlegal Fishing) [Perpres 115/2015] membentuk Satgas 115. Secara kelembagaan, keberadaan Satgas 115 untuk mendukung upaya peningkatan penegakan hukum terhadap pelanggaran dan kejahatan di bidang perikanan khususnya penangkapan ikan secara ilegal berada di bawah dan bertanggung jawab langsung kepada Presiden.

Satgas bertugas mengembangkan dan melaksanakan operasi penegakan hukum dalam upaya pemberantasan penangkapan ikan secara ilegal di wilayah laut yurisdiksi Indonesia secara efektif dan efisien dengan mengoptimalkan pemanfaatan personil dan peralatan operasi, meliputi kapal, pesawat udara, dan teknologi lainnya yang dimiliki oleh Kementerian Kelautan dan Perikanan, TNI-AL, Polri, Kejaksaan Agung Republik Indonesia, Badan Keamanan Laut, Satuan Kerja

15 Yunus Husein, "Indonesia's Approach in Tackling Fisheries Crime Strategy on Combating IUU Fishing and Post Moratorium Policies Plan", Paper presented at The Symposium on Fish Crime, 12-13 October 2015, Cape Town, South Africa, hlm. 30. 
Khusus Pelaksana Kegiatan Usaha Hulu Minyak dan Gas Bumi, PT Pertamina, dan institusi terkait lainnya. Berdasarkan Pasal 2 ayat (1) Perpres 115/2015, tugas Satgas 115 juga meliputi kegiatan perikanan yang tidak dilaporkan (unreported fishing).

Adapun kewenangan Satgas 115 adalah sebagai berikut:

1) Menentukan target operasi penegakan hukum dalam rangka pemberantasan penangkapan ikan secara ilegal;

2) Melakukan koordinasi dalam pengumpulan data dan informasi yang dibutuhkan sebagai upaya penegakan hukum, dengan institusi terkait termasuk tetapi tidak terbatas pada Kementerian Kelautan dan Perikanan, Kementerian Keuangan, Kementerian Luar Negeri, Kementerian Perhubungan, TNI-AL, Polri, Kejaksaan Agung Republik Indonesia, Badan Keamanan Laut, Pusat Pelaporan dan Analisis Transaksi Keuangan, Badan Intelijen Negara;

3) Membentuk dan memerintahkan unsur-unsur satgas untuk melaksanakan operasi penegakan hukum dalam rangka pemberantasan penangkapan ikan secara ilegal di kawasan yang ditentukan oleh satgas; dan

4) Melaksanakan komando dan pengendalian sebagaimana dimaksud pada huruf c yang meliputi kapal, pesawat udara, dan teknologi lainnya dari TNI-AL, Polri, Kementerian Kelautan dan Perikanan, serta Badan Keamanan Laut yang sudah berada di dalam satgas.

Menurut Penulis, desain kelembagaan pencegahan dan pemberantasan illegal fishing di Indonesia masih memiliki kelemahan terutama pada kelembagaan pengadilan perikanan beserta kewenangannya, begitu juga Satgas 115. Yurisdiksi pengadilan perikanan yang hanya mengadili tindak pidana perikanan saja, sesungguhnya tidak sinkron dengan kondisi yang ada di lapangan. Praktik illegal fishing yang terjadi tidak hanya tindak pidana perikanan saja tetapi meliputi tindak pidana yang berhubungan dengan tindak pidana illegal fishing seperti perbudakan, pekerjaan paksa, money laundering, hingga pelanggaran hak asasi manusia (HAM). Dengan demikian, pengadilan perikanan tidak memiliki kewenangan untuk mengadili tindak pidana yang berhubungan dengan tindak pidana perikanan (fishing crime). Begitu juga kewenangan Satgas 115 yang hanya memiliki kewenangan untuk melakukan operasi penegakkan hukum dan pemberantasan illegal fishing dan unreported fishing. Sementara di lapangan menurut temuan Satgas 115 illegal fishing berhubungan dengan tindak pidana lainnya di bidang perikanan (crime related fishing) seperti perbudakan, pekerjaan paksa, money laundering, dan pelanggaran imigrasi yang bukan menjadi kewenangan satgas. ${ }^{16}$

Menyadari kelemahan kewenangan pengadilan perikanan dan Satgas 115 di atas, menurut Penulis konsep kelembagaan pencegahan dan pemberantasan illegal

16 Mas Ahmad Santosa, "Indonesia's Multi-door Approach in Combating Fisheries Crime, the Fight against Fisheries and Associated Crimes in Indonesia", Paper presented at The Symposium on Fish Crime, 12-13 October 2015, Cape Town, South Africa, hlm. 27. 
fishing dapat dilakukan dengan menambah kewenangan pengadilan perikanan tidak saja kewenangan di bidang illegal fishing tetapi juga kewenangan untuk mengadili tindak pidana yang berkaitan dengan perikanan (fishing-related crime). Sedangkan konsep Satgas 115 dilakukan dengan menambah kewenangan Satgas 115 tidak saja kewenangan di bidang illegal fishing tetapi juga kewenangan di bidang tindak pidana yang berkaitan dengan perikanan (fishing-related crime) juga tindak pidana lain yang berkaitan dengan kelautan. Model ini dapat diterapkan dengan melakukan perubahaan terhadap UU Perikanan dan perubahan terhadap Perpres 115/2015.

\section{Model Kerjasama Internasional dalam Pencegahan dan Pemberantasan Illegal Fishing}

Setelah dilakukan penelitian ditemukan bahwa corak illegal fishing adalah sifatnya yang lebih dari satu tindak pidana (multi-criminal act) dan bersifat lintas batas negara (transnational crime). Oleh karena itu, model pencegahan illegal fishing di samping model multi doors juga perlu model kerjasama internasional dalam memberantas illegal fishing. Berdasarkan temuan Satgas 115 terdapat 14 modus operandi kejahatan illegal fishing di Indonesia, yaitu: ${ }^{17}$

1. Pemalsuan dokumen kapal (Forgery of vessel's document);

2. Kapal berbendera ganda dan pendaftaran ganda (Double flagging \& double registered);

3. Penangkapan ikan tanpa izin/dokumen yang diperlukan (Fishing without licenses/appropriate documents, sailing without port and seaworthiness clearance);

4. Modifikasi kapal secara ilegal (IIlegal modification of vessel, including marked down, changing call sign, machines);

5. Tidak ada sertifikat kesehatan dan pernyataan ekspor (Absence of health certificate and export declaration);

6. Pelanggaran wilayah perikanan (Violation of fishing ground);

7. Menggunakan alat tangkap yang dilarang (Using prohibited fishing gear);

8. Menggunakan kapten kapal dan pelaut asing (Using foreign captain and seamen);

9. Tidak mengaktifkan alat transmitter kapal (Deactivation of Vessel's Transmitter [VMS] and AIS);

10.Pengalihan muatan kapal secara ilegal dalam laut (Illegal transhipment at sea);

11.Pemalsuan buku catatan (Forgery of logbook record);

12.Pendaratan hasil tangkapan tidak sesuai dengan hukum (Unlawful landing of catches); dan

17 lbid. 
13. Ketidakpatuhan pemilik atau mitra dalam proses perikanan (Non-compliance in owning/partnering with a fish processing).

Berdasarkan temuan Satgas 115 kejahatan yang terjadi pada praktik perikanan ilegal di Indonesia tidak saja illegal fishing tetapi juga ditemukan jenis tindak pidana yang berkaitan dengan perikanan (fishing-related crime). Terdapat 8 (delapan) jenis kejahatan berkaitan dengan perikanan yakni:

1. Transaksi bahan bakar mineral (BBM) ilegal (Illegal transaction offuel);

2. Tindak pidana di bidang keimigrasian (Immigration related crime);

3. Tindak pidana di bidang bea cukai (Customs related crime incl. smugglings of drugs, protected species, vessel spare parts and other goods);

4. Pencucian uang (Money laundering);

5. Perdagangan obat terlarang (Illicit Drugs Trafficking);

6. Tindak pidana perburuhan (Labor related crimes: modern slavery, human trafficking and child labor);

7. Tindak pidana bidang perpajakan; dan

8. Tindak pidana korupsi. ${ }^{18}$

Delapan jenis tindak pidana yang berkaitan dengan perikanan di atas menunjukkan adanya unsur kejahatan yang bersifat transnasional (transnational organized crime-TOC). Menurut Yunus Husen, anggota Satgas 115, tindak pidana yang berhubungan dengan illegal fishing memenuhi unsur sebagai kejahatan transnasional terorganisasi, pertama, kejahatan tersebut melibatkan lebih dari satu pelaku dengan kewarganegaraan yang berbeda dan diorganisir dengan baik (terorganisasi), kedua, kejahatan tersebut merupakan kejahatan yang serius (it should be classified as serious crime), dan ketiga, hasil kejahatan dimaksudkan untuk tujuan ekspor ke negara lain.

Kejahatan kapal bendera ganda dan pendaftaran ganda (double flagging \& double registered), penggunaan kapten kapal asing dan pelaut asing, serta kejahatan yang menggunakan alat tangkap terlarang (using prohibited fishing gears) sesungguhnya telah memenuhi sebagai kejahatan transnasional terorganisasi dengan unsur-unsur: pertama, melibatkan pelaku kejahatan lebih dari satu negara (involve in more than one countries); kedua, kejahatan ini disiapkan dan dikontrol dari negara lain (prepared and controlled from another country); ketiga, kejahatan ini berdampak pada timbulnya korban perdagangan manusia yang kewarganegaraanya lebih dari satu negara; dan, keempat, memiliki dampak serius bagi negara lain yaitu menurunnya persediaan ikan global.

Pada modus kejahatan pemindahan muatan kapal secara ilegal di tengah laut (Illegal transshipment at sea) juga menunjukkan sifat TOC-nya, yaitu melibatkan lebih dari satu negara, ikan ditangkap di perairan Indonesia secara ilegal kemudian 
dipindahkapalkan di tengah laut untuk dibawa ke negara seperti dalam kasus kapal Benjina.

Menyadari bahwa illegal fishing dan fishing crime memiliki sifat sebagai TOC maka sangat sulit untuk mencegah dan memberantasnya tanpa kerjasama internasional antar negara, sementara di sisi lain hingga kini berbagai perjanjian internasional baik di bidang hukum laut dan perikanan internasional maupun perjanjian pidana internasional belum memasukan kedua jenis kejahatan di atas sebagai kejahatan transnasional. ${ }^{19}$

Indonesia sebagai negara yang paling berkepentingan dengan isu pencegahan dan pemberantasan illegal fishing perlu menggalakan kerja sama internasional. Oleh karena itu, menurut Penulis model kerjasama internasional yang dapat dilakukan oleh Indonesia dalam mencegah dan memberantas kerjasama internasional adalah sebagai berikut:

Pertama, Indonesia menginisasi dan memperjuangkan disahkannya perjanjian tentang anti illegal fishing (convention on combat illegal fishing) seperti yang dilakukan oleh Indonesia ketika menjadi negara terdepan menggalakan kerja sama internasional di bidang pemberantasan tindak pidana korupsi (United Nations Convention Against Corruption-UNCAC), perjanjian anti perdagangan orang, dan anti money laundering. Perjuangan Indonesia yang tepat dijadikan contoh adalah ketika Indonesia mampu menjadikan negara kepulauan sebagai salah satu rezim hukum yang diakui dalam hukum laut internasional (Konvensi Hukum Laut 1982).

Kedua, Indonesia dapat memperjuangkan untuk disahkannya perjanjian internasional yang bersifat regional, misalnya Association of South-East Asian Nations (ASEAN). Indonesia turut mempunyai andil ketika memperjuangkan disahkannnya perjanjian internasional pemberantasan korupsi di bawah kerangka hukum ASEAN. Berdasarkan kenyataan bahwa illegal fishing dan fishing crime melibatkan warga negara ASEAN maka Indonesia sangat wajar untuk dapat berjuang kembali menjadikan illegal fishing dan fishing crime sebagai kejahatan transnasional di Asean.

Ketiga, Indonesia dapat melakukan kerjasama internasional secara bilateral dengan negara-negara lain dimana asal pelaku illegal fishing dan fishing crime dalam bentuk kerja sama ekstradisi dan kerja sama di bidang pidana perikanan (mutual legal assistance in criminal matters).

Keempat, Indonesia dapat memasukan kerja sama internasional dalam perubahan terhadap UU Perikanan. Dalam undang-undang ini diatur berbagai kerjasama internasional yang dapat dilakukan pemerintah untuk mencegah dan memberantas illegal fishing dan fishing crime.

19 Teale N. Phelps Bondaroff, (et.al), The Illegal Fishing and Organized Crime Nexus: Illegal Fishing as Transnational Crime, Geneva, Netherlands: The Global Initiative Against Transnational Organized Crime, 2015, hlm. 51. 


\section{Model Pendekatan Multi-Door Pencegahan dan Pemberantasan Illegal Fishing}

Sebagaimana diuraikan di atas, illegal fishing dan fishing crime dalam pemberantasan illegal fishing yang dilakukan Satgas 115 memiliki keterkaitan dengan tindak pidana lain di luar illegal fishing (fishing-related crime). Jenis tindak pidana seperti transaksi BBM ilegal (illegal transaction of fuel), tindak pidana di bidang keimigrasian (immigration related crime), tindak pidana di bidang bea cukai (customs related crime including smugglings of drugs, protected species, vessel spare parts and other goods), pencucian uang (money laundering), perdagangan obat terlarang (illicit drugs trafficking), tindak pidana perburuhan (labor related crimes: modern slavery, human trafficking, and child labor), tindak pidana bidang perpajakan, dan tindak pidana korupsi menjadikan tindak pidana ini tidak hanya menggunakan proses penegakan hukum di bidang tindak pidana perikanan sebagaimana diatur dalam UU Perikanan semata, tetapi juga melibatkan rezim undang-undang yang lain yang mengatur tindak pidana di atas. Di samping itu, aparat penegak hukum yang terlibat didalamnya harus melibatkan penegak hukum di bidang sektoral dengan kejahatan di bidang perikanan di atas tidak saja melibatkan anggota Satgas 115 .

Menurut Penulis, model pencegahan dan pemberantasan illegal fishing dan fishing crime dapat dilakukan dengan dua track. Pertama, multi-door rezim hukum. Upaya pencegahan dan pemberantasan illegal fishing dapat dilakukan dengan menggunakan rezim hukum lain selain rezim illegal fishing dalam undang-undang perikanan. Untuk mencegah dan memberantas praktik transaksi BBM ilegal (illegal transaction of fuel) di laut maka dapat digunakan rezim hukum minyak dan gas bumi, sedangkan untuk tindak pidana di bidang keimigrasian (immigration related crime) maka dapat digunakan undang-undang keimigrasian. Terhadap tindak pidana di bidang bea cukai termasuk penyelundupan obat terlarang, penyelundupan satwa terlarang (customs related crime including smugglings of drugs, protected species, vessel spare parts and other goods) dapat digunakan undangundang kepabeanan, undang-undang anti narkoba, dll. Terhadap tindak pidana pencucian uang (money laundering) maka digunakan rezim hukum anti pencucian uang. Terhadap tindak pidana perdagangan obat terlarang (illicit drugs trafficking) maka dapat digunakan undang-undang anti perdagangan orang. Terhadap tindak pidana perburuhan (Labor related crimes: modern slavery, human trafficking and child labor), maka dapat digunakan undang-undang ketenagakerjaan, undangundang anti perdagangan orang, dan undang-undang perlindungan. Begitu juga pada tindak pidana bidang perpajakan dan tindak pidana korupsi maka pelaku kejahatan dapat dikejar dengan undang-undang perpajakan dan undang-undang pemberantasan korupsi. 
Kedua, menggunakan unsur penegak hukum yang berada di luar Satgas 115. Sejalan dengan pemikiran multi-door rezim hukum di atas, maka pada tataran penegak hukumnya pun harus melibatkan multi-legal officer, tidak hanya Satgas 115. Menurut Penulis, untuk mengefektifkan pencegahan dan pemberantasan illegal fishing dan fishing crime harus juga melibatkan Komisi Pemberantas Korupsi (KPK), Pusat Pelaporan dan Analisis Transaksi Keuangan (PPATK), Badan Narkotika Nasional (BNN), Bea Cukai, Penyidik Pegawai Negeri Sipil (PPNS) Lingkungan Hidup, dan PPNS Ketenagakerjaan harus juga bagian dari Satgas 115.

\section{Model Koordinasi Satuan Tugas Pusat dan Daerah dalam Pencegahan Pemberantasan Illegal Fishing: Model Nusa Tenggara Barat}

Locus delicti terjadinya illegal fishing tidak hanya terjadi pada wilayah terluar dan ZEE Indonesia, tetapi juga terjadi pada wilayah perairan kepulauan Indonesia bahkan perairan pedalaman Indonesia. Oleh karena itu upaya pencegahan dan pemberantasan illegal fishing tidak hanya melibatkan Satgas 115 yang umumnya berada di pemerintah pusat, tetapi juga melibatkan pemerintah daerah. Keanggotaan satgas ternyata tidak berimbas pada kerjasama pencegahan dan pemberantasan illegal fishing di daerah. Keanggotaan satgas itu sendiri merupakan sebagai berikut:

a. Komandan Satgas: Menteri Kelautan dan Perikanan,

b. Kepala Pelaksana Harian: Wakil Kepala Staf TNI-AL;

c. Wakil Kepala Pelaksana Harian 1: Kepala Badan Keamanan Laut;

d. Wakil Kepala Pelaksana Harian 2: Kepala Badan Pemelihara Keamanan, Polri; dan

e. Wakil Kepala Pelaksana Harian 3: Jaksa Agung Muda Bidang Tindak Pidana Umum, Kejaksaan Agung Republik Indonesia.

Berdasarkan penelitian yang Penulis lakukan pada Dinas Perikanan dan Kelauatan Provinsi Nusa Tenggara Barat (NTB), jumlah kasus illegal fishing yang terjadi di NTB pada tahun tahun 2015 terjadi sebanyak 10 kasus dengan dengan modus yang beragam. Hal ini tentu memerlukan kerja sama antar lembaga penegak hukum di daerah. Oleh karena itu diperlukan sebuah kerja sama pencegahan dan penegakkan hukum antara Satgas 115 dan pemerintah daerah (pemda).

Pada tataran daerah upaya pencegahan dan pemberantasan illegal fishing dilakukan dengan langkah-langkah: pertama, membuat nota kesepahaman (memorandum of understanding) antara penegak hukum dan pemerintah daerah. Penegak hukum di bidang perikanan seperti kepolisian, TNI-AL, dan Kejaksaan Tinggi yang memiliki kewenangan untuk melakukan penegakkan hukum di bidang illegal fishing di daerah harus dilibatkan. Kedua, ruang lingkup kerjasama tidak saja pencegahan illegal fishing tetapi juga mencakup tindak pidana kelautan di Provinsi NTB. 
Berdasarkan wawancara penulis dengan Staf Dinas Kelautan dan Perikanan NTB, Pemda NTB telah melakukan inisiatif untuk membuat rancangan memorandum of understanding (MoU) dengan ketiga lembaga penegak hukum di atas dengan ruang lingkup:

a. Perencanaan Pencegahan dan Penegakan Tindak Pidana Kelautan dan Perikanan (Illegal, Unreported, Unregulated, Destructive Fishing);

b. Sosialisasi Pencegahan dan Penegakan Tindak Pidana Kelautan dan Perikanan (Illegal, Unreported, Unregulated, Destructive Fishing);

c. Penindakan Tindak Pidana Kelautan dan Perikanan (Illegal, Unreported, Unregulated, Destructive Fishing);

d. Penegakan Hukum terhadap Tindak Pidana Kelautan dan Perikanan (Illegal, Unreported, Unregulated, Destructive Fishing);

e. Pembentukan Forum Penanganan Tindak Pidana Kelautan dan Perikanan (FPTPKP) di tingkat provinsi dan Satgas Penanganan Tindak Pidana Kelautan dan Perikanan (Illegal, Unreported, Unregulated, Destructive Fishing) di tingkat lapangan yang ditetapkan dengan Surat Keputusan Gubernur Nusa Tenggara Barat; dan

f. Pengawasan dan pengendalian dengan jajaran instansi di bawahnya tetap berkoordinasi dengan pemerintah kabupaten/kota dan Unit Pelaksana Teknis (UPT) kementerian/lembaga terkait.

Kedua, selain MoU di atas, Pemda NTB telah merencanakan untuk menginisiasi pembentukan Tim Forum Koordinasi Penanganan Tindak Pidana Kelautan dan Perikanan Provinsi Nusa Tenggara Barat melalui Keputusan Gubernur NTB. Adapun keanggotaan forum ini terdiri dari 25 instansi yang bergerak di bidang penegakan hukum bidang kelautan dan perikanan. Selain itu, fungsi forum tersebut adalah:

1) koordinasi kegiatan penyidikan tindak pidana bidang kelautan dan perikanan;

2) identifikasi jenis, modus operandi, volume dan penyebaran praktik-praktik tindak pidana bidang kelautan dan perikanan;

3) penyuluhan dan pembinaan kepada masyarakat untuk mencegah terjadinya tindak pidana di bidang kelautan dan perikanan;

4) analisis, identifikasi, dan pengukuran signifikansi tindak pidana di bidang kelautan dan perikanan secara periodik;

5) perancangan bentuk-bentuk koordinasi kegiatan-kegiatan pemberantasan tindak pidana di bidang kelautan dan perikanan;

6) perumusan dan pemutakhiran strategi pemberantasan tindak pidana di bidang kelautan dan perikanan;

7) pemantauan dan penyajian laporan pelaksanaan pemberantasan tindak pidana di bidang kelautan dan perikanan; dan

8) pengkajian dan evaluasi efektifitas srategi pemberantasan tindak pidana di bidang kelautan dan perikanan. 
Dengan kelembagaan dan bentuk koordinasi dan kerjasama pecegahan dan pemberantasan illegal fishing seperti di atas, maka konsep kerjasama dan koordinasi yang baik antara Satgas 115 dan Pemda dapat berjalan dengan baik.

Ketiga, peningkatan kapasitas hakim pada peradilan umum. Sebagaimana diketahui bahwa UU Perikanan telah mengamanatkan pembentukan pengadilan perikanan yang kewenangannya memeriksa dan memutuskan perkara tindak pidana perikanan. Namun pengadilan perikanan tidaklah dibentuk untuk seluruh wilayah hukum Indonesia melainkan hanya pada 5 (lima) pengadilan yaitu di Pengadilan Negeri Jakarta Utara, Medan, Pontianak, Bitung, dan Tual. Hingga kini di NTB belum memiliki pengadilan perikanan tersendiri. Oleh karena itu, menyadari urgensinya hakim yang menguasai perikanan maka hakim yang pada pengadilan negeri yang memiliki tingkat tindak pidana perikanan yang tinggi seperti NTB harus dilakukan peningkatan kapasitas dan kualitas sehingga dapat mengadili perkara tindak pidana perikanan secara profesional dan mewujudkan keadilan.

\section{Penutup}

1. Kesimpulan

a. Model pencegahan dan pemberantasan illegal fishing di Indonesia adalah model pencegahan dan pemberantasan illegal fishing yang komprehensif dan terkoordinasi (comprehensive and coordinated in preventing and combating illegal fishing). Model tersebut didasarkan pada suatu landasan visi Indonesia sebagai negara maritim yang memandang laut sebagai masa depan bangsa Indonesia. Visi pembangunan maritim didasarkan pada visi pembangunan di bidang kelautan dan perikanan, yakni: "Mewujudkan Sektor Kelautan dan Perikanan Indonesia Yang Mandiri, Maju, Kuat dan Berbasis Kepentingan Nasional" dengan pilar pembangunan kelautan dan perikanan, yaitu kedaulatan (sovereignty), keberlanjutan (sustainability), dan kesejahteraan (prosperity).

b. Pembentukan model-model pencegahan dan pemberantasan illegal fishing yang komprehensif dan terkoordinasi (compressive and coordinated in preventing and combating illegal fishing) didukung oleh beberapa komponen model, yaitu: Pertama, model kelembagaan pencegahan dan pemberantasan illegal fishing yaitu model multi-institusi; kedua, model kerja sama internasional dalam pencegahan dan pemberantasan illegal fishing dengan mendorong menjadikan illegal fishing sebagai kejahatan transnasional terorganisasi; ketiga, model pendekatan multi-door pencegahan dan pemberantasan illegal fishing dengan menggunakan rezim hukum pidana yang lain di luar pidana perikanan; dan keempat, model koordinasi satgas pusat dan daerah dalam pencegahan pemberantasan illegal fishing yang didasarkan pada model di NTB. 


\section{Saran}

Untuk dapat merealisasikan model pencegahan dan pemberantasan illegal fishing yang komprehensif dan terkoordinasi (comprehensive and coordinated in preventing and combating illegal fishing maka diperlukan langkah operasional pada tataran kebijakan pemerintah, yakni sebagai berikut:

a. Untuk mewujukan model kelembagaan pencegahan dan pemberantasan illegal fishing yang multi-institusi maka hendaknya Presiden Indonesia melakukan perubahan terhadap Perpres 115/2015 dengan memasukan Dirjen Bea Cukai, KPK, Kementerian Ketenagakerjaan, dan PPATK sebagai anggota Satgas 115.

b. Untuk mewujudkan kerja sama internasional yang efektif dalam pencegahan dan pemberantasan illegal fishing maka hendaknya Kementerian Kelautan dan Perikanan, Kementerian Luar Negeri, serta Kementerian Hukum dan HAM, melakukan rapat koordinasi untuk mendesain kerjasama internasional melalui saluran diplomatik pada organisasi internasional seperti United Nations Office on Drugs and Crime (UNODOC) PBB, Food and Agriculture Organization (FAO) PBB, dan ASEAN untuk menginisiasi kerjasama internasional yang dituangkan dalam perjanjian internasional tentang Perjanjian Kerjasama Memerangi Illegal Fishing.

c. Untuk mewujudkan model multi disiplin pencegahan dan pemberantasan illegal fishing maka hendaknya Dewan Perwakilan Rakyat dan Presiden melakukan perubahan terhadap UU Perikanan dengan memasukan tambahan kewenangan pengadilan perikanan yaitu kewenangan mengadili kejahatan yang berkaitan dengan perikanan (fishing crime).

d. Untuk mewujudkan model koordinasi satgas pusat dan daerah dalam pencegahan dan pemberantasan illegal fishing maka hendaknya Kementerian Kelautan dan Perikanan berkoordinasi dengan pemerintah daerah untuk membentuk satgas pencegahan dan pemberantasan illegal fishing di daerah sebagaimana dilakukan oleh pemerintah Provinsi NTB.

\section{Daftar Pustaka}

\section{Buku}

Bondaroff, Teale N. Phelps, (et.al), The Illegal Fishing and Organized Crime Nexus: Illegal Fishing as Transnational Crime, The Global Initiative Against Transnational Organized Crime, Geneva, Netherlands, 2015.

Daud Silalahi, Peranan Hukum dalam Mengaktualisasikan Prinsip-Prinsip Pembangunan Berkelanjutan, Alumni, Bandung, 1997.

Dikdik Mohamad Sodik, Hukum Laut Internasional dan Pengaturannya di Indonesia, Refika Aditama, Bandung, 2014.

Etty R Agoes, Konvensi Hukum Laut 1982: Masalah Pengaturan Hak Lintas Kapal Asing, CV. Abardin, 1991. 
Gatot Dwi Hendro Wibowo, Hukum Konservasi Lautan: Kerangka Hukum

Pengelolalaan Ekosistem Terumbu Karang untuk Keanekaragaman Hayati Lautan, 2010.

Kementerian Kelautan dan Perikanan, Laporan Satu Tahun Kinerja KKP, KKP RI, Jakarta, 2015.

Koesnadi Hardjasoemantri, Hukum Tata Lingkungan, Edisi Ke-7, Cetakan ke-17, Gadjah Mada University Press, Yogjakarta, 1999.

Pocut Eliza, Laporan Akhir Analisis Dan Evaluasi Hukum Dalam Rangka

Pemberantasan Kegiatan Perikanan Liar (IUU fishing), Pusat Analisis dan

Evaluasi Hukum Nasional, Badan Pembinaan Hukum Nasional Kementerian Hukum dan HAM RI Tahun 2016, Jakarta.

Sands, Philipe, Principles of International Environmental Law, 1995.

Siti Sundari Rangkuti, Hukum Lingkungan dan Kebijaksanaan Lingkungan Nasional, Edisi Kedua, Air Langga University Press, 2000.

\section{Dokumen Lain}

Daud Silalahi, "Pembangunan Berkelanjutan Dalam Rangka Pengelolaan (Termasuk Perlindungan) Sumber Daya Alam Yang Berbasis Pembangunan Sosial Dan Ekonomi", Makalah Disampaikan Pada Seminar Pembangunan Hukum Nasional Viii Tema Penegakan Hukum Dalam Era Pembangunan Berkelanjutan, diselenggarakan oleh Badan Pembinaan Hukum Nasional Departemen Kehakiman dan HAM, Denpasar, 14-18 Juli 2003.

Diding Sutardi, "Tak Ada Tempat Bagi Perampok Ikan”, Majalah Mina Bahari, Edisi 01 Apr - Jun 2015.

Dikdik Mohamad Sodik, "Combating Illegal, Unreported, and Unregulated Fishing in Indonesian Waters: Need for Fisheries Legislative Reform", Disertasi, Wolonglong University, 2007.

Mas Ahmad Santosa, "Indonesia's Multi-door Approach in Combating Fisheries Crime, the Fight against Fisheries and Associated Crimes in Indonesia", Paper presented at The Symposium on Fish Crime, 12-13 October 2015, Cape Town, South Africa.

Susi Pudjiastuti, "Fisheries Crime As Transnational Organized Crime", Makalah disampaikan pada Pertemuan di Singapura, 17 November 2015.

Yunus Husein, "Indonesia's Approach in Tackling Fisheries Crime Strategy on Combating IUU Fishing and Post Moratorium Policies Plan", Paper presented at The Symposium on Fish Crime, 12-13 October 2015, Cape Town, South Africa. 


\section{Dokumen Hukum}

Undang-Undang Nomor 45 Tahun 2009 tentang Perubahan terhadap UndangUndang Nomor 31 Tahun 2004 tentang Perikanan.

Peraturan Presiden Republik Indonesia Nomor 115 Tahun 2015 Tentang Satuan Tugas Pemberantasan Penangkapan Ikan Secara Ilegal (Illegal Fishing). 